\title{
Isoseismal maps drawing by the kriging method
}

\author{
Z. Schenková • V. Schenk • I. Kalogeras • R. Pichl • \\ P. Kottnauer • C. Papatsimba - G. Panopoulou
}

Published online: 13 June 2007

(C) Springer Science + Business Media B.V. 2007

\begin{abstract}
Macroseismic intensity, a useful measure of earthquake effects, is still applied in a wide range of seismological applications like seismic hazard assessments, attenuation relationships, etc. Isoseismals represent the spatial distribution of macroseismic intensities, and their shapes depend on source properties, lithosphere structures, tectonic line orientations, site geology, and topography. The applications ask for both the higher number of isoseismal maps, and their standardization and homogenization. The point kriging gridding method for an automatic computer drawing of isoseismal maps was delivered. Smoothing rates and numerical parameters used in the kriging algorithm were tested on macroseismic data of Greek earthquakes representing
\end{abstract}

The online version of the original article can be found at http://dx.doi.org/10.1007/s10950-006-9023-1.

Z. Schenková $(\bowtie) \cdot$ V. Schenk $\cdot$ R. Pichl $\cdot$ P. Kottnauer Institute of Rock Structure and Mechanics,

Academy of Sciences,

V Holešovičkách 41,

CZ - 18209 Praha 8, Czech Republic

e-mail: zdschenk@irsm.cas.cz

I. Kalogeras $\cdot$ C. Papatsimba $\cdot$ G. Panopoulou

National Observatory of Athens, Geodynamic Institute,

248, 11810 Athens, Greece

I. Kalogeras

e-mail: i.kalog@egelados.gein.noa.gr different tectonic and geomorphological regimes. The optimum kriging default option was defined. Its application for four Greek earthquakes is presented and discussed from the viewpoint of a broad use in recent macroseismology.

Keywords Isoseismal maps $\cdot$ Kriging method · Macroseismic observations · Greece

Erratum to: J Seismol (2007) 11:121-129

DOI 10.1007/s10950-006-9023-1

\section{Introduction}

For many years, macroseismic intensity is a useful measure used in various studies covering a wide range of seismological applications. The observed macroseismic intensities contribute to assess the magnitude of a given event and/or amount of seismic energy released during the event, especially the historical ones. It has to be particularly appointed that macroseismic data are the only information describing seismic damage effects of the historical earthquakes for which no instrumental recordings exist. In the last decades, the importance of macroseismic data knowledge increased substantially due to reliable evaluations of seismoactive zones in which strong and destructive earthquakes occur and which have to be involved in calculations of reasonable 
earthquake hazard assessments. From the observed intensity values distribution for an earthquake and from the individual isoseismal shapes, the focal parameter estimations and intensity attenuation with distance can be determined (Galanopoulos 1961; Everden 1975; Papaioannou 1984; Papazachos 1992). Frankel (1994) and Johnston (1996) denoted if a good quality of intensity data, the moment magnitude and attenuation relationship, for an earthquake-felt area are comparable to those of instrumental data. From all the reasons mentioned above, the isoseismal maps still play an important role in many theoretical tasks and engineering applications (Theodulidis and Papazachos 1992).

The problem of drawing relative objective isoseismals is a centennial one (Sirovich et al. 2002). There are the differences between contours obtained by various experts. An international experiment (Cecić et al. 1996), when the same macroseismic data sets for a number of European earthquakes were supplied to 16 authors from 11 European countries, describes all these uncertainties. It is necessary to standardize and to homogenize the process of isoseismal map drawing to obtain reasonable and applicable results. Approaches introduced previously, which applied the circular and/or elliptical models for the isoseismal drawing (Shebalin 1974; Papazachos et al. 1982; Papazachos et al. 1997), can hardly be used in recent studies.

During the last decade, different geostatistical approaches for the objectivity improvement in isoseismal tracing were proved, namely, the naturalneighbors and the kriging techniques. The first one is a concept of computational geometry describing properties of arbitrarily distributed points in any number of dimensions. The second one is a geostatistical gridding method based on the theory of regionalized variables that allows visually appealing maps from irregularly spaced data to be produced.

Pettenati et al. (1999) and Sirovich et al. (2002) proposed an algorithm of the natural-neighbour $(n-n)$ coordinates for weighting, interpolating, and contouring the irregularly distributed macroseismic observations. $n-n$ Isoseismals were proposed as a new tool that would solve the problem of drawing objective and reproducible isoseismals from earthquake damage sparsely observed. In their approximation, the surface of irregularly distributed observations was partitioned into a unique set of Voronoi polygons computed on a fine regular grid. The authors stated "a happy compromise between the crude objectivity of the Voronoi tessellation and the intuitive appeal of the somewhat subjective classical isoseismals." The $n-n$ isoseismals do not increase the complexity of quantitative source inversion because of no increase of the number of unknowns in contouring parameters.

Krige $(1951,1962)$ developed the optimal method of data interpolation for use in the mining industry (Burrough and McDonell 1998). Details on the kriging method and its algorithm can be found in Matheron (1971), Journel and Huijbregts (1978), Journel (1989), Cressie (1990, 1991), Isaaks and Srivastava 1989, Burrough and McDonell (1998), etc. More information on a computer code is given in Deutsch and Journel (1992) including a well-documented source code library of geostatistics computer programs in Fortran and in the Golden Software (2004).

The present paper gave an interest in the kriging approach to macroseismic intensity data and automatic isoseismal map drawing. Main emphasis was put to a computing acquisition of a faithful map solution for one earthquake and, if possible, to a definition of any sophisticated kriging default option allowing such maps for majority of observed macroseismic data to be obtained. For this purpose, a lot of kriging option tests on the Greek macroseismic data collected by the Geodynamic Institute of the National Observatory of Athens (GINOA) from the period 1956-2003 were realized.

The GINOA has collected macroseismic observations since its establishment in 1893, following generally the same procedure using the modified Mercalli (MM) intensity scale. The assessed macroseismic intensities are published in the GINOA monthly bulletins. For some earthquakes, the isoseismal maps drawn by an expert's hand are included in the bulletins. Macroseismic fields of the Balkan area were studied in detail by Papazachos and Papaioannou (1997, 1998). In the last years, GINOA develops the macroseismic database aiming two targets: the semiautomatization of the macroseismic observations collection and the manipulation of information connected to the macroseismic intensities (Kalogeras et al. 2004).

In this paper, isoseismal maps of only four earthquakes are presented, epicenters of which differ partly on their positions to dry land and partly on their density of intensity observations. These isoseismal maps are discussed also from the viewpoint of the routine kriging default option application in standard macroseismology. 


\section{Kriging method and isoseismal map drawing}

The kriging gridding methods are being generally used for regionalized variables that describe phenomena with geographical distribution like ground-water modeling, soil mapping, and related fields. They are incorporated as modules in many recent commercial GIS packages. Kriging reflects the density distribution of the known points, provides an error estimation and confidence interval for every unknown point, and gives the degree of spatial autocorrelation, modeling in such a way regional trends and local anomalies. In short, kriging is a distance weighting estimation method that takes advantage of the spatial characteristics of the local structure through the variogram function.

Latest applications of kriging techniques to macroseismic intensity data for their interpolation and filtering for removing possible errors carried out by Gasparini et al. (2003) and De Rubeis et al. (2005) concluded that the introduction of experimental semivariogram is a useful tool in solving this problem. The reconstruction of a synthetic intensity showed that sampling density might be important, but the effect of data errors on the reliability of the reconstructed field seemed to be stronger. The authors validated their proposed approach on intensity observations of Italian moderate events and concluded that it provides valuable results for further seismic investigations such as seismic-risk assessment or site-response studies.

The main accent of kriging applications presented in this paper was directed to the determination of kriging default option for automatical isoseismal maps drawing under the same computational conditions from macroseismic observations of different earthquakes. Then, if computational conditions are identical, then, mutually normalized and homogenized isoseismal maps will be drawn.

To carry out comprehensive analyses of various kriging options, a relative homogeneous database of wide-ranging macroseismic data bank gathered, by GINOA, for shallow and intermediate earthquakes that occurred in the period 1965-2003 with epicenter intensity $I_{0}$ varying between IV and VIII MM56. Kriging calculations were realized by the Surfer program package for Windows, product of Golden Software (2004).

Kriging algorithm can act either as an exact or a smoothing interpolator that allows weights of inter-data spacing, inherent length scale, repeatability, and natural anisotropy of the considered data to be assessed and incorporated. The essential kriging parameters are entered into the algorithm via the variogram. The length scale is given by the variogram range (or slope), the data repeatability is specified by the nugget effect, and the anisotropy is given by the anisotropy itself. It was decided that the point kriging, contrary to the block kriging, which produces a slight data smoothing, estimates the values of the points at the grid nodes and fits better to the observed macroseismic intensities. After comprehensive analyses, a common variogram was assessed and, by its mean kriging default option, was assigned. It allowed unbiased incorporating of minimum variable parameters to be determined, too. The recommended kriging default option gives the following default linear variogram function parameters:

1. To use the no search option-because out data sets contain frequently less than 1,000 observation points

2. To introduce the nugget effect $N=1$ and the linear variogram slope $S=1$; these values fits to the ratio $N / S=1$; under that, a reasonable smoothing of individual isoseismals exist

3. To put anisotropy $A=1$ because every macroseismic field is represented more or less by a "bell" data distribution on the Earth's surface

This kriging process is demonstrated on the following four earthquakes with different macroseismic fields concerning a density of observation points, a range of intensity values and an earthquake position with respect to a dry land area:

(a) The Amorgos, Central Aegean 1956 earthquake

(b) The Peloponnese 1965 earthquake

(c) The Kozani-Grevena, Northern Greece 1995 earthquake

(d) The Athens 1999 earthquake

\section{Kriging isoseismal maps}

Macroseismic observations evaluated with respect to a certain macroseismic scale should be homogenized before their application in any automatic procedure, including the proposed kriging method. If intensity observations are influenced by a human approach (different structure building types, increasing effects 
of higher floors, etc.), it is recommended before kriging to correct observations for standard building and for the Earth's surface.

As to potential geological site effects, they have to be taken as sources of "objective uncertainties" involved in macroseismic observations besides the other uncertainties joined to subjective data assessment by different evaluators. Macroseismic practice accounts that only a small number of macroseismic intensity observations is significantly influenced by local site effects. From this viewpoint, approximated intensity values by kriging represent a regional macroseismic field, and intensity differences between observed and approximated values allow local site effects to be detected and even to be assessed with a high resolution.

\section{The Amorgos 1956 earthquake}

This catastrophic earthquake occurred in Central Aegean on July 9th, $1956\left(H=03: 12, \varphi=36.7^{\circ} \mathrm{N}, \lambda=\right.$ $25.8^{\circ} \mathrm{E}$, normal depth, $\left.I_{\max }=\mathrm{IX}, M_{\mathrm{S}}=7.5\right)$ and struck mainly the Cyclades islands (Amorgos, Santorini, Anaphi, Astypalaea, Ios, Paros, Naxos). According to reports (Monthly Bulletin of GINOA 1956), 529 houses were totally destroyed, and 1,482 houses
Fig. 1 The Amorgos 1956 earthquake isoseismals

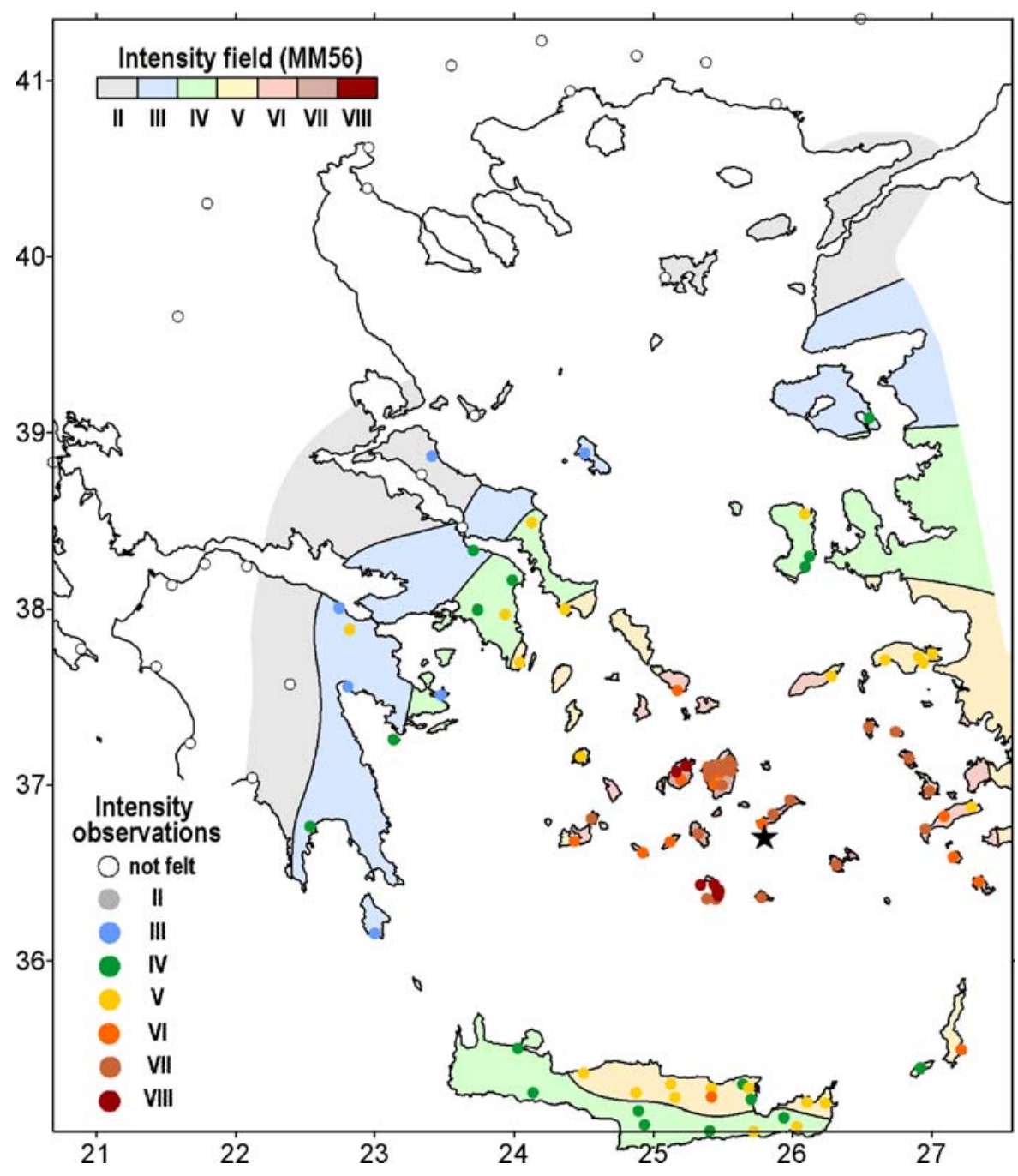


showed partial damage; 53 persons were killed and 100 were injured. After the occurrence of the earthquake, a tsunami followed showing a maximum height of $25 \mathrm{~m}$ at the $\mathrm{SE}$ coasts of Amorgos and a minimum height of $0.15 \mathrm{~m}$ at Rhodes Island. Altogether, 124 macroseismic observations were collected by GINOA. Isoseismal maps for this event were compiled by Shebalin (1974) and Papazachos et al. (1997).

It became apparent that, although intensities of IX (1), VIII+ (3), and VIII (3) were reported from the islands of Amorgos, Santorini, and Paros, the highest isoseismal drawn by the kriging approach was VII (Fig. 1). This could be attributed to the small number of the high intensities concentrated within a limited area (seven observations per $146 \mathrm{~km}^{2}$ ) in view of the total number of observations (124 observations from roughly the quarter of Greek territory). It is a question if $7(\sim 5 \%)$ observations of 131 can represent convincingly the isoseismal area of VIII. In comparison, the isoseismals by Shebalin (1974) and Papazachos et al. (1997) show the same elongated shape to the ENE-WSW direction as the inner isoseismals drawn by kriging method, but on the other hand, both previous maps have the isoseismal of VIII.

\section{The Peloponnese 1965 earthquake}

The earthquake occurred in central Peloponnese on April 5th, $1965\left(H=03: 13, \varphi=37.4^{\circ} \mathrm{N}, \lambda=22.1^{\circ} \mathrm{E}\right.$; normal depth, $M_{\mathrm{S}}=6.1$ ). According to 446 observations collected by GINOA (Monthly Bulletin of GINOA 1965), 1,426 houses collapsed, 7,051 houses showed damage beyond any repair, and 15,906 houses showed slighter damage. Eighteen persons were killed, and 17 were injured. The damage occurred mainly within eight administrative districts. In the epicentral area, the ground cracks, and fissures appeared in sections having lengths between 30 and $500 \mathrm{~m}$ and widths between 3 and $5 \mathrm{~cm}$. Isoseismals are cited in Shebalin (1974) and in Papazachos et al. (1997).

The highest intensities of $\mathrm{X}$ (three in an area of $27 \mathrm{~km}^{2}$ ) and IX (four in an area of $39 \mathrm{~km}^{2}$ ) were reported, and the further 439 macroseismic observations
Fig. 2 The Peloponnese 1965 earthquake isoseismals

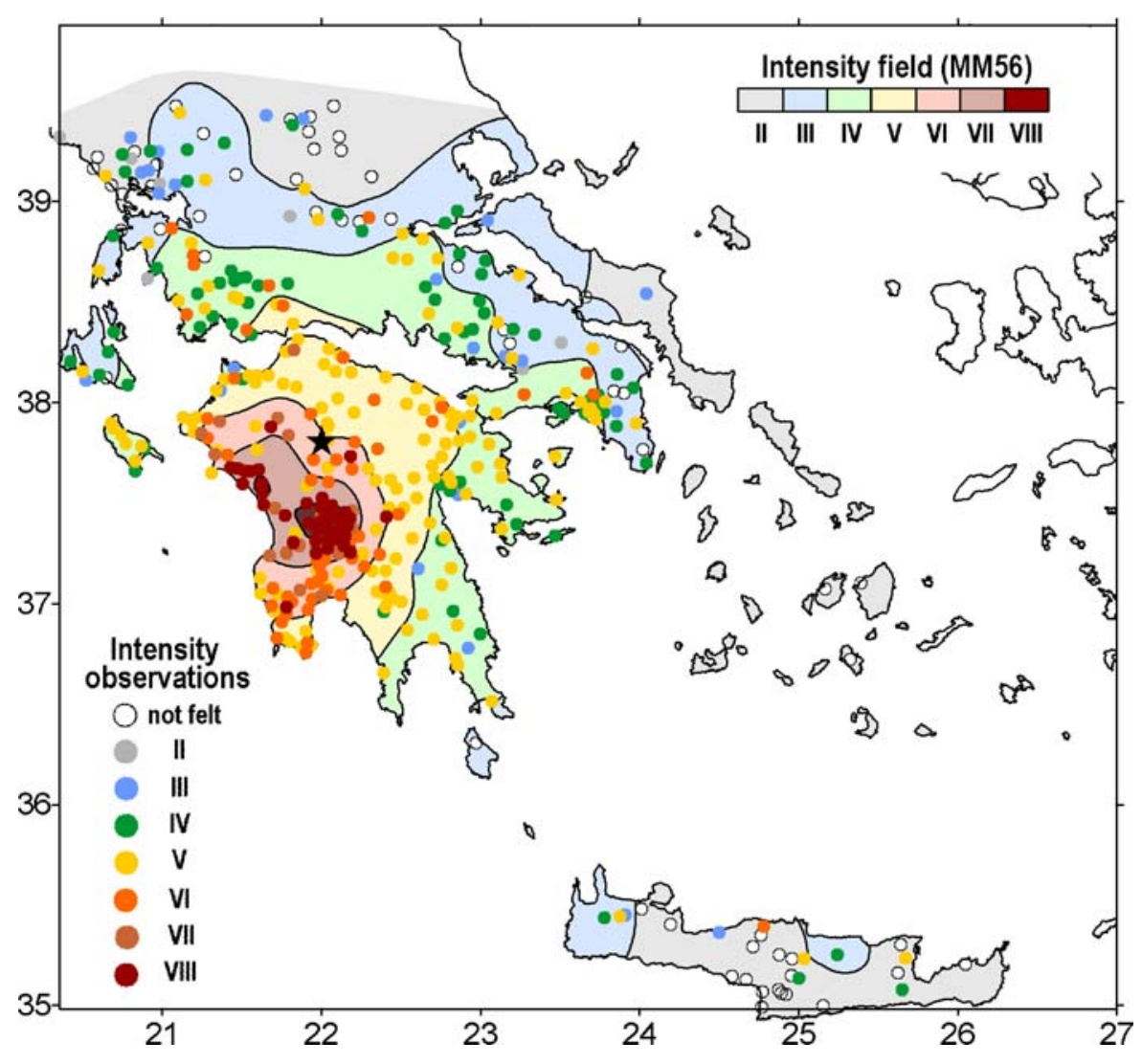


covered almost half of the Greek territory. Similarly, as for the Amorgos 1956 event, it is impossible to consider $1.5 \%$ of the total number of reported macroseismic observations occurring in areas of $5 \times 6$ or $6 \times 7 \mathrm{~km}$ for the adequate number of observations for drawing the isoseismal of IX. Therefore, the kriging highest isoseismal of VIII was adopted (Fig. 2), while in macroseismic maps drawn by Drakopoulos (in Shebalin 1974) and by Papazachos et al. (1997), the isoseismals of IX were constructed.

The kriging isoseismal map (Fig. 2) indicates slight the NW-SE orientation due to inner distribution of intensities of $\mathrm{X}$ and IX, which form two spots surrounded by the meizoseismal area. This direction corresponds to an elongation of the isoseismals drawn by Drakopoulos (Shebalin 1974) but not to the isoseismals of Papazachos et al. (1997) that display the opposite NE-SW orientation.
It has to be mentioned that if a number of lines and rows of the grid matrix was increased, what could be assumed as a way to obtain a map portrayed in more details, the isoseismal shapes did not change at all. Actually, this fact is rather important for the kriging default applications because it proves that a uniformity of the isoseismal field is independent on the grid matrix.

\section{The Kozani-Grevena 1995 earthquake}

At 08:47:17 GMT on May 13, 1995, an $M_{\mathrm{S}}=6.6$ earthquake occurred in Northwestern Macedonia (Galanakis et al. 1998; Hatzfeld et al. 1997; Mountrakis et al. 1998; Papazachos et al. 1998) and caused damages at the broader area of the cities of Grevena and Kozani. The earthquake that originated in this area was rated by low historical seismicity. GINOA
Fig. 3 The KozaniGrevena 1995 earthquake isoseismals

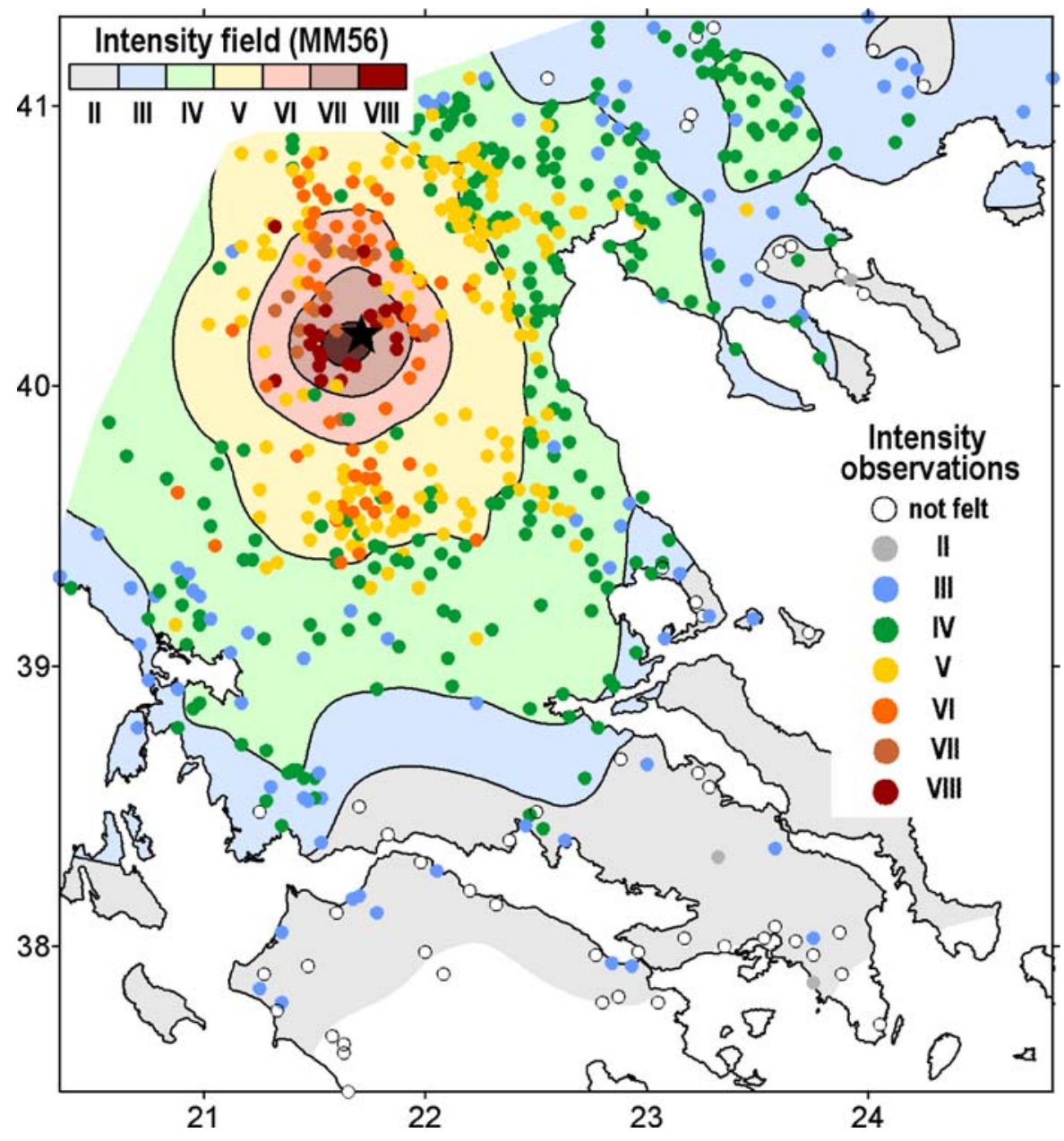


collected altogether 657 macroseismic observations delivered from 29 Greek administrative districts (Monthly Bulletin of GINOA 1995). The maximum observed intensity reached the grade of IX+ MM56. Gathered data show that the majority of continental Greece was shaken (Fig. 3). Major destruction of housing occurred in several towns and villages and on the road network; changes at the water level of wells and the water flow of springs, rock falls, and landslides were observed all over the area. No was death reported due to the earthquake, probably because of five foreshocks about half an hour before the main shock with local magnitudes of $M_{\mathrm{L}}<4$ that alarmed people to leave their houses. Isoseismals of this earthquake are included in Galanakis et al. (1998) and in Papazachos et al. (1997).
The highest kriging isoseismal (Fig. 3) is that of VIII, which is in agreement with the isoseismal map of Papazachos et al. (1997) and could be clearly attributed to the small number of reported high intensities of IX (two observations for $128 \mathrm{~km}^{2}$ ).

\section{The Athens 1999 earthquake}

On 7 September 1999, at 11:57:50 GMT, an earthquake of $M_{\mathrm{S}}=5.9$ struck Athens, the capital of Greece (Louvari and Kiratzi 2001; Papadopoulos et al. 2000; Pavlides et al. 2002; Roumelioti et al. 2002, 2003; Tselentis and Zahradník 2000). The maximum observed intensity was graded at IX MM56. The epicenter was located at the southwestern slope of the Parnitha Mt.,

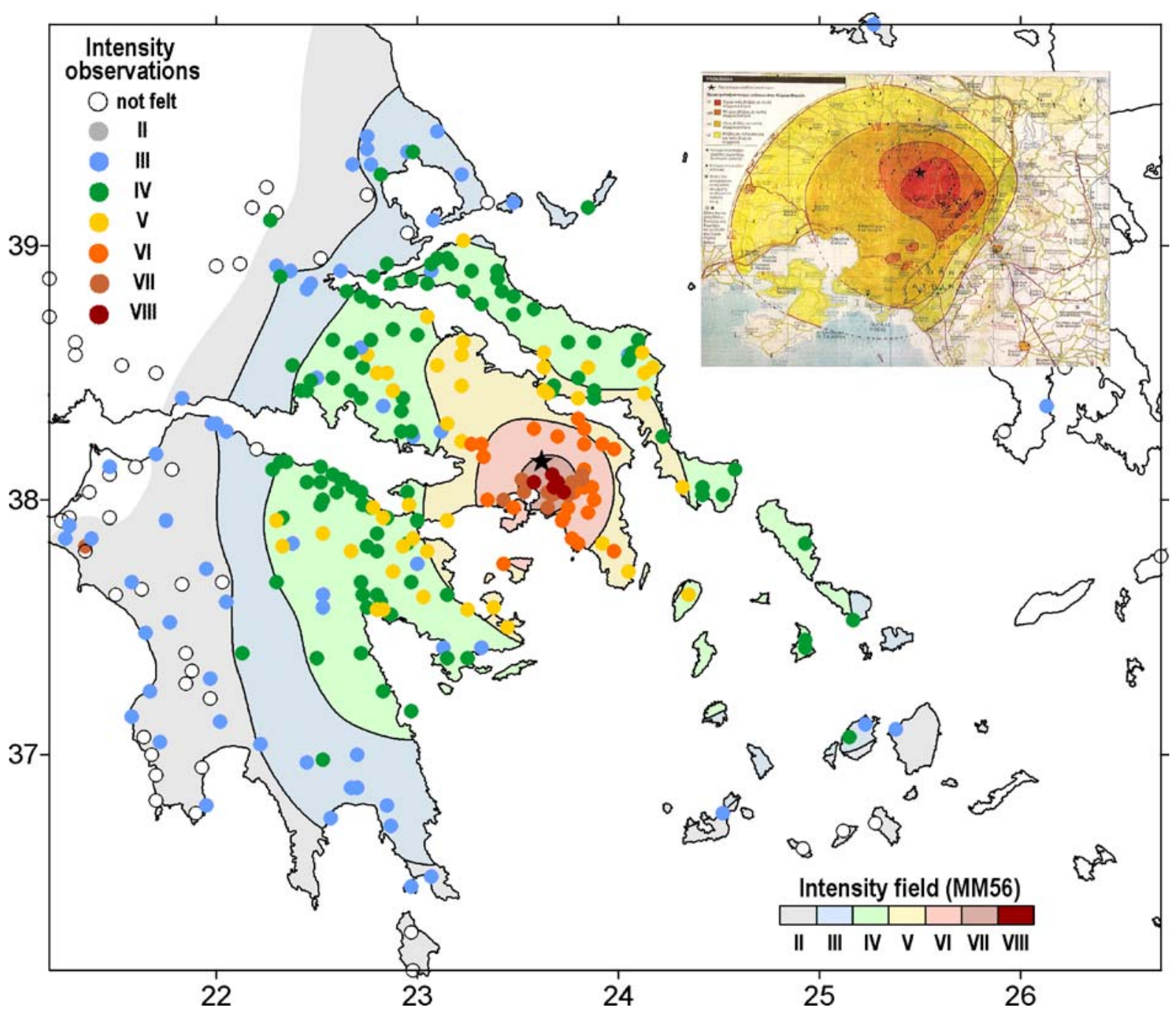

Fig. 4 The Athens 1999 earthquake isoseismals; Protonotario's isoseismal map is at the right upper corner 
about $20 \mathrm{~km}$ far from the town center. Due to high population density and collapses of residential buildings and factories, 143 deaths and about 800 injuries were reported regardless of the moderate magnitude of the shock (Papadopoulos et al. 2000). GINOA gathered 323 macroseismic questionnaires from 16 administrative districts (Monthly Bulletin 1999). According to reports, the Athens earthquake shook an area up to epicentral distances of 200-250 km.

In the newspaper Kathimerini (1999), the isoseismal map that delivered the highest isoseismal of IX compiled by Protonotarios was published (Fig. 4). He gave a journalistic preference to the reports from three municipalities covering an area of $190 \mathrm{~km}^{2}$ with respect to other observations. In total, other five reports exist for an intensity of VIII from an area of $90 \mathrm{~km}^{2}$. The map in Fig. 4 shows a kriging isoseismal of VII as the highest one. Protonotarios' map gave higher preference to Athens reports and did not display a regional character of the whole macroseismic field. Nevertheless, the isoseismals belonging to the meizoseismal area of the Athens 1999 event given in our kriging solution and those in hand-made Protonotarios' map display significant similarity.

\section{Conclusions}

At present, when isoseismal maps ought to be compiled, an existence of a drawing approach exploiting an available computation technology would be helpful, and everybody could use it. Moreover, such approach should introduce standardization and homogenization into the map drawing. Among various geostatistical gridding approaches, the kriging seems to be a suitable tool for computations in isoseismal map drawing. A reliability of the kriging method was systematically investigated with respect to different gridding parameters, and the optimum kriging default option for isoseismal map drawing was defined. It is understandable that certain thresholds in its applications exist as a number of observations per area, an extent of macroseismic intensities observed with respect to the maximum observed intensity, etc. The isoseismal maps of four Greek earthquakes from different parts of Greece calculated and drawn by kriging were presented and compared with the maps of other investigators. The absence of the highest isoseismals in kriging approach depends on an occurrence rate between individual intensity levels. The presented isoseismal maps deliver high efficiency of the kriging approach for various levels of observation distribution and their areal density.

Generally, parts inside of the isoseismal maps can be classified as more reliable than the parts outside where isoseismal fields could be shaped in a wrong way because of marginal conditions of the data distribution. Thus, the effectiveness of their reliability has to be assessed individually with respect to applied data. For macroseismic practice, a rather important item is that kriging default option allows isoseismal maps to be drawn under the same conditions, i.e., the same level of standardization and homogenization in their drawing will be always kept. Moreover, a significance of this map drawing will be emphasized more and more when a great number of such maps will be gathered into any atlas of isoseismal maps (e.g. Schenková et al. 2005) and when they could be used as inputs for the earthquake hazard assessment and/or for land and urban planning tasks.

Acknowledgment This work was funded partially by the bilateral Czech-Greek agreement, the projects no. RC_3_13 and KonTAKT ME694, both of the Ministry of Education, Youth and Sports of the Czech Republic; by the Greek General Secretariat of Research and Technology; and partially by the programs of the Academy of Sciences of the Czech Republic for the support of the target research and development $\mathrm{S}$ 3012007 , the basic science research in the key areas of science K 304/61/08, and the IRSM research plan A VOZ 30460519. The authors would like to express their gratitude to both institutes, namely the Institute of Rock Structure and Mechanics Academy of Sciences, Prague, and to GINOA for providing data and support for the realization of this study.

\section{References}

Burrough PA, McDonell (1998) Principles of geographical information systems. Oxford University Press

Cecić I, Musson MW, Stucchi M (1996) Do seismologists agree upon epicentre determination from macroseismic data? A survey of ESC Working Group "Macroseismology". Annali di Geofisica 39(5):1013-1027

Cressie NAC (1990) The origins of kriging. Math Geol 22:239-252

Cressie NAC (1991) Statistics for spatial data. Wiley, New York, $900 \mathrm{pp}$

De Rubeis V, Tosi P, Gasparini C, Solipaca A (2005) Application of kriging technique to seismic intensity data. Bull Seismol Soc Am 95:540-548

Deutsch CV, Journel AG (1992) GSLIB-Geostatistical Software Library and user's guide. Oxford University Press, New York, pp 338

Everden JF (1975) Seismic intensities, 'size' of the earthquakes and related parameters. Bull Seismol Soc Am 65:1287-1313 
Frankel A (1994) Implication of felt area-magnitude relations for earthquake scaling and the average frequency of perceptible ground motion. Bull Seismol Soc Am 84(2):462-465

Galanopoulos A (1961) On magnitude determination by using macroseismic data. Annali di Geofisica 14:401-408

Galanakis D, Rondogianni TH, Kourouzidis M (1998) The unexpected Kozani-Grevena earthquake of May 13, 1995. In: Pavlidis S (ed) The Kozani-Grevena earthquake of May 13, 1995—scientific and social approach. Institute of Book and Reading, Kozani, pp 59-68

Gasparini C, Tosi P, De Rubeis V (2003) Northern Sicily, September 6, 2002 earthquake: Investigation on peculiar macroseismic effects. Ann Geophys 46:1361-1366

Hatzfeld D, Karakostas V, Ziazia M, Selvaggi G, Leborgne S, Berge C, Guiguet R, Paul A, Voidomatis PH, Diagourtas D, Kassaras J, Koutsikos J, Makropoulos K, Azzara R, Dibona M, Bacchechi S, Bernard P, Papaioannou Ch (1997) The Kozani-Grevena (Greece) earthquake of May 13, 1995, revisited from a detailed seismological study. Bull Seismol Soc Am 87:463-473

Isaaks EH, Srivastava RM (1989) An Introduction to applied geostatistics. Oxford University Press, New York, pp 561

Johnston AC (1996) Seismic moment assessment of earthquakes in stable continental regions-II. Historical seismicity. Geophys J Int 125:639-678

Journel AG, Huijbregts C (1978) Mining geostatistics. Academic, $600 \mathrm{pp}$

Journel AG (1989) Fundamentals of geostatistics in five lessons. American Geophysical Union, Washington, DC

Kalogeras I, Kourouzidis M, Schenková Z, Schenk V, Stavrakakis G (2004) Macroseismic observations in Greece. Development of a database for extraction of new knowledge. The 29th General Assembly of the ESC book. University and GFZ, Potsdam

Kathimerini newspaper (1999) September 23rd (in Greek)

Krige DG (1951) A statistical approach to some basic mine valuation problems on the Witwatersrand. J Chem Metall Min Eng Soc S Afr 52(6):119-139

Krige DG (1962) Effective pay limits for selective mining. J S Afr Inst Min Metall 62:345-363

Louvari E, Kiratzi A (2001) Source parameters of the 7 September 1999 Athens (Greece) earthquake based on teleseismic data. J Balk Geophys Soc 4(3):51-60

Matheron G (1971) The theory of regionalized variables and their applications. Les Cahiers du Centre de Morphologie Mathematique de Fontainebleau 5, 212 pp

Mountrakis D, Pavlides S, Zouros N, Astaras TH, Chatzipetros A (1998) Seismic fault geometry and kinematics of the 13 May 1995 Western Macedonia (Greece) earthquake. J Geodyn 26:175-196

Monthly Bulletin of GINOA (1956) National Observatory of Athens, Geodynamic Institute (July)

Monthly Bulletin of GINOA (1965) National Observatory of Athens, Geodynamic Institute (April)

Monthly Bulletin of GINOA (1995) National Observatory of Athens, Geodynamic Institute (May)

Monthly Bulletins of GINOA (1999) National Observatory of Athens, Geodynamic Institute (September)

Papadopoulos GA, Drakatos G, Papanastassiou D, Kalogeras I, Stavrakakis G (2000) Preliminary results about the catastrophic earthquake of 7 September 1999 in Athens, Greece. Seism Res Lett 71(3):318-329

Papaioannou CA (1984) Attenuation of seismic intensities and seismic hazard in Greece and surrounding area (in Greek). PhD thesis, University of Thessaloniki, pp 200

Papazachos CB (1992) Anisotropic radiation modelling of macroseismic intensities for estimation of attenuation structure of the upper crust in Greece. Pure Appl Geophys 138: 445-469

Papazachos BC, Comninakis PE, Hatzidimitriou PM, Kiriakidis EC, Kiratzi AA, Panagiotopoulos DG, Papadimitriou EE, Papaioannou CA, Pavlides SB, Tzanis E (1982) Atlas of Isoseismal Maps for Earthquakes in Greece 1902-1981. Geophys Lab Univ Thessaloniki Publ 4:126

Papazachos BC, Karakostas BG, Kiratzi AA, Papadimitriou EE, Papazachos CB (1998) A model for the 1995 KozaniGrevena seismic sequence. J Geodyn 26:217-231

Papazachos BC, Papaioannou CA (1997) The macroseismic field in the Balkan area. J Seismol 1:181-201

Papazachos BC, Papaioannou CA (1998) Further information on the macroseismic field of the Balkan area. J Seismol $2: 363-375$

Papazachos BC, Papaioannou CA, Papazachos CB, Savvaidis AA (1997) Atlas of isoseismal maps for strong earthquakes in Greece and surrounding area (426 B.C.-1995). Geophys Lab Univ Thessaloniki Publ 4, pp 126

Pavlides SB, Papadopoulos GA, Ganas A (2002) The fault that caused the Athens September $1999 M_{\mathrm{S}}=5.9$ earthquake: field observations. Nat Hazards 27:61-84

Pettenati F, Sirovich L, Cavallini F (1999) Objective treatment and synthesis of macroseismic intensity data sets using tessellation. Bull Seism Soc Am 89:1203-1213

Roumelioti Z, Kiratzi AA, Theodulidis N, Kalogeras I, Stavrakakis G (2002) Rupture directivity during the September 7, $1999\left(M_{\mathrm{w}}\right.$ 5.9) Athens (Greece) earthquake inferred from forward modeling of strong motion. Pure Appl Geophys 160:2301-2318

Roumelioti Z, Dreger D, Kiratzi AA, Theodulidis N (2003) Slip distribution of the 7 September 1999 Athens earthquake inferred from an empirical Green's function study. Bull Seism Soc Am 93:775-782

Schenková Z, Kalogeras I, Schenk V, Pichl R, Kourouzidis M, Stavrakakis G (2005) Atlas of isoseismal maps of selected Greek earthquakes (1956-2003). Evonymos Ecolog Library, Athens

Shebalin NV (ed) (1974) Atlas of isoseismals. Part III: Survey of the seismicity of the Balkan Region. UNDP/UNESCO, Skopje, 275 pp

Sirovich L, Cavallini F, Pettenati F, Bobbio M (2002) Naturalneighbor isoseismals. Bull Seismol Soc Am 92:1933-1940

Golden Software (2004) Surfer program package for Windows: user's guide. Golden Software, Golden, CO

Theodulidis N, Papazachos B (1992) Dependence of strong ground motion on magnitude-distance, site geology and macroseismic intensity for shallow earthquakes in Greece. I: Peak horizontal acceleration, velocity and displacement. Soil Dyn Earthqu Eng 11:387-402

Tselentis GA, Zahradník J (2000) The Athens earthquake of 7 September 1999. Bull Seismol Soc Am 90(95):1143-1160 